\title{
İlkokul Öğrencilerinin Empresyonizme Yönelik Görüşlerinin Görsel Okuryazarlık Bağlamında İncelenmesi
}

\section{Reviewing of Primary School Students' Views On Impresionism In The Context of Visual Literacy}

\author{
Yahya Hiçyılmaz a,* \\ ${ }^{a}$ Dr. Öğr. Üyesi, Van Yüzüncü Yıl Üniversitesi Eğitim Fakültesi, Güzel Sanatlar Eğitimi, Van/Türkiye. \\ ORCID: 0000-0003-3453-9998
}

\section{MAKALE BİLGİSİ}

\section{Makale Geçmişi:}

Başvuru tarihi: 2 Ocak 2020

Düzeltme tarihi: 7 Şubat 2020

Kabul tarihi: 23 Mart 2020

\section{Anahtar Kelimeler:}

Görsel okuryazarlık

Empresyonizm

Öğrenciler

\section{ÖZ}

$\mathrm{Bu}$ araştırmanın amacı, ilkokul döneminde öğrenim gören öğrencilerin empresyonizm sanat akımına yönelik görüşlerini görsel okuryazarlık bağlamında incelemektir. Araştırma, amaç ve yöntem açısından betimleyici bir yaklaşım izlenerek yürütülmüştür. Araştırmanın çalışma grubu, 526 öğrenci ile oluşturulmuştur. Veri toplama araçlarını belirlemek amacıyla Empresyonizm sanat akımının üç dönemine ait birer manzara resmi, üç görsel sanatlar uzmanın görüşleri doğrultusunda seçilmiştir. Veriler, içerik analizi ve tanımlayıcı istatistik teknikleri ile analiz edilmiştir. Araştırmanın sonucunda, öğrencilerin Empresyonizm sanat akımının son dönemine ait eserlere daha çok ilgi duydukları bulunmuştur. Öğrencilerin ilgi duydukları tabloları, daha çok eserin konusunu temel alarak seçtikleri görülmüştür. Ayrıca öğrencilerin Empresyonizm sanat akımının son dönemine ait eserlerinin görsel okur ve görsel yazarlık unsurlarına yönelik açıklamalarının daha fazla olduğu belirlenmiştir. Çalışmada, elde edilen sonuçlardan hareketle ilkokul öğrencilerinin farklı sanat eserlerine yönelik görsel okuryazarlık çerçevesinde düşüncelerini ifade edebileceği ortamların oluşturulması önerilmektedir.

\section{A B S T R AC T}

The aim of this study is to examine the views of the elementary school students towards Impressionism art movement in the context of visual literacy. The research was conducted with a descriptive approach in terms of purpose and method. The study group of the study was formed with 526 students. In order to determine the data collection tools, a landscape painting belonging to three periods of Impressionism art movement was chosen according to the opinions of three visual arts experts. Then, the collected data were analysed in terms of content analysis and descriptive statistics. According to the results of the study, it was determined that the students were more interested in the works of the last period of Impressionism art movement. It was seen that the paintings which the students were interested in were those based on the subject matter of the work. In addition, it was determined that the students have more explanations about visual literacy of the works belonging to the last period of Impressionism art movement. In the research, based on the results obtained, it is recommended to create environments where primary school students can express their thoughts for different works of art within the framework of visual literacy.

\section{Giriş}

Hızlı değişme ve gelişmelerin yaşandı̆̆ı bir dünyada bilginin aktarılma şeklinde değişiklikler meydana gelmiştir. Görsel kültürün etkisinde yetişen yeni nesil (Z-Kuşağı); web, fotoğrafa bağlı sosyal ağlar, video, medya ve grafiksel olarak gelişmiş oyunlar aracılığıyla sunulan görsel iletişimlere giderek daha fazla güvenmektedir (Metros, 2008). "Net nesil" olarak adlandırılan yeni nesil, gittikçe görüntü tabanlı medya ve dijital çağın tüm diğer araç- gereçleri ile daha fazla zaman harcamaktadır (Prensky, 2001). Bu ortamda resimler veya görsel veriler, bilgiyi ve duyguları iletmek için neredeyse yazının yerini almıştır (Meyer, 2010). Yeni dijital teknolojiler, hemen hemen herkesin görselleri oluşturmasına ve paylaşmasına olanak sağlamaktadır. Ancak görsellerin yaygın olması, bireylerin görsel içeriği eleştirel olarak görüntüleyebildikleri, kullandıkları ve ürettikleri anlamına gelmez. Bu bağlamda görsel okuryazarlık becerilerinin yetişen yeni nesle

\footnotetext{
* Sorumlu yazar/Corresponding author e-posta: yahya-04@windowslive.com
} 
kazandırılması, yeni neslin görsel kültüre tam olarak katılmasına ortam sağlamaktadır.

Görsel okuryazarlık, görsel imgeleri (resimsel ve grafiksel) eleştirel olarak anlama, yorumlama ve yaratma becerisi şeklinde tanımlanabilir (Brown, 2004; Lopatovska, Hatoum, Waterstraut, Novak ve Sheer, 2016; Wileman, 1993). Görsellerle iç içe olan bir dünyada görsel okuryazarlık, görsellerle daha derin iletişime geçmek için kritik bir öneme sahiptir. Görsel okuryazarlık becerileri; görsel malzemelerinin üretimini gerçekleştirmek, görsellerin kültürel, etik, estetik ve teknik bileşenlerini anlamak ve analiz etmek için bireyi donatmaktadır. Dolayısıyla görsel okuryazarlık, bireylerin görsel medya dünyasında gezmelerini sağlayan önemli bir beceridir. $\mathrm{Bu}$ bağlamda öğrencilerin görselleri oluşturmak, yorumlamak ve sorgulamak için donanımlı olması gerekmektedir (Brown, 2004; Roblyer ve Bennett, 2001).

Öğrenciler, kendilerini çevreleyen görsel kültürden sürekli olarak etkilendiğinden, görsel okuryazarlık becerilerinin yaşamın erken dönemlerinde geliştirilmesi kritik önem taşımaktadır (Lopatovska ve diğ., 2016). Bu becerilerin erken yaşlardan itibaren kazanılması; sözel becerileri geliştirme, kendini ifade etme, çeşitli konularda motivasyon sağlama ve özgüveni geliştirmede öğrencilere avantajlar sağlayabilir (Flynt ve Brozo, 2010).

Sanat eğitiminin ilk ve ortaöğretim kademelerindeki uygulama alanı Görsel Sanatlar dersidir. Bu ders, ruhsal ve beden eğitiminde bireylerin estetik duygularını geliştirmeyi, yeteneklerini ve yaratıcılıklarını olgunlaştırmayı amaçlayan bir alan olarak görülmektedir (Çakıroğlu ve İnce, 2015). Görsel Sanatlar Dersi Öğretim Programının amaçlarından biri de; görsel okuryazarlık, algı ve estetik bilincine sahip ve farklı kültürlerde ortaya konulan sanat eserlerini ve sanatçıları inceleyen bireyler yetiştirmektir. (MEB, 2018). Buradan hareketle bireyin gelişiminde sanatın kültürel ve bilişsel boyutunun da göz önünde bulundurulması gerektiği anlaşılmaktadır. Bu anlamda Empresyonizm (İzlenimcilik) sanat akımı Görsel Sanatlar eğitiminin doğal bir parçasıdır. Görsel Sanatlar eğitimin amacı, bireye eleştirel bir bakış açısı kazandırmaktır. Bu bakış açısı da öğrencilere görsel okuryazarlık becerilerin kazandırılması ile geliştirilebilir. $\mathrm{Bu}$ bağlamda bu çalışma ilkokul öğrencilerinin Görsel Sanatlar dersinin bir konusu olan Empresyonizm sanat akımına yönelik görüşlerini, görsel okuryazarlık çerçevesinde incelemeyi hedeflemektedir.

Empresyonizm sanat akımının teknolojik gelişmelere bağlı olarak 1800'lü yılların sonlarına doğru ortaya çıktığı görülmektedir. $\mathrm{Bu}$ dönemin sanatçıları, teknikteki yeni deneysel çalışmaları yansıtmaktadır. Bu dönemde renklere yaratıcı bir gözle yaklaşan sanatçılar, Empresyonizm sanatını bir adım daha öteye taşıyarak Neo-Empresyonizm ve Post Empresyonizm olarak bilinen akımları kurmuşlardır. Bu gelişmeler sanat dünyasında yeni bir sayfa açmıştır. Empresyonizm olarak adlandırılan bu akım, neredeyse kendisinden sonra çıkan tüm akımları peşinden sürüklemiştir (Ayaydın, 2015). "Empresyonist sanatçılara göre, resim sanatı izlenimlerin yansitılması olayıdır" (Ayaydın, 2015 s. 88). Empresyonizm adını, Claude Monet'in yapmış olduğu "İzlenim, Gündoğumu" adlı tablodan almıştır. Monet, ışık üzerinde titizlikle çalışan ve rengin resim alanında biçim kadar etkileyici olabileceğini hisseden ilk ressamdır (Tansuğ, 2006).
Literatür incelendiğinde, küçük çocuklar üzerinde görsel okuryazarlık becerileri ile ilgili bazı araştırmaların yapıldığı görülmektedir. Lopatovska ve diğ. (2016), küçük çocukların görsel okuryazarlık unsurları hakkındaki bilgilerini ve yeni tanıtılan görsel okuryazarlık kavramlarını anlamaya yönelik yeteneklerini incelemişlerdir. O'Neil (2011) çalışmasında, öğrencilerin resimli kitaplardaki öykülerin çizgi, renk gibi görsel okuryazarlık unsurları çerçevesinde, anlamaya ve bu doğrultuda görsel okuryazarlık becerilerini geliştirmeye yönelik aktiviteleri sunmuştur. Pantaleo (2016), küçük çocukların görsel sanat ve tasarım öğelerini öğrenmelerinin görsel imgeleri yorumlamasına etkisini incelemiştir. $\mathrm{Bu}$ araştırmaların dışında, yetişkinlerde görsel okuryazarlık becerileri ile ilgili birçok çalışma bulunmaktadır (Loerts ve Belcher, 2019; Sadik, 2009; Şahin ve Kıran, 2009; Yerlikaya, 2016). Ancak, ilkokul döneminde öğrenim gören öğrencilerin Empresyonizm sanat akımına yönelik görüşlerini görsel okuryazarlık bağlamında inceleyen bir araştırmaya rastlanmamıştır. Bu doğrultuda araştırmanın literatüre katkı sağlayacağ 1 düşünülmektedir. Bu düşünceden hareketle bu araştırmada, ilkokul öğrencilerinin Empresyonizm sanat akımına yönelik görüşlerinin görsel okuryazarlık bağlamında incelenmesi amaçlanmıştır. $\mathrm{Bu}$ amaç doğrultusunda araştırmanın cevap aradığı sorular şunlardır:

1) Öğrencilerin ilgi duydukları sanat eserleri cinsiyetlerine ve sınıf düzeylerine göre değişmekte midir?

2) Öğrencilerin sanat eserlerine yönelik ilgi duyma nedenleri cinsiyetlerine ve sinıf düzeylerine göre değişmekte midir?

3) Öğrencilerin görsel okur ve görsel yazarlık unsurlarına yönelik açıklamaları sanat eserlerine, cinsiyetlerine ve sınıf düzeylerine göre nasıl bir dağılım göstermektedir?

\section{Yöntem}

$\mathrm{Bu}$ bölümde araştırmanın desenine, çalışma grubuna, veri toplama araçlarına, verilerin toplanmasına ve verilerin analizine yönelik bilgilere yer verilmektedir.

\subsection{Araştırmanın Deseni}

Araştırmada, amaç ve yöntem açısından betimsel araştırma metotlarından tarama (survey) yöntemi kullanılmıştır. Tarama modeli, "geçmişte ya da halen var olan bir durumu var olduğu şekliyle betimlemeyi amaçlayan araştırma yaklaşımıdır" (Karasar, 1991, s. 77). Araştırmacı, amacına bağlı olarak anket ya da görüşme formu gibi veri toplama araçları kullanabilir (Creswell, 2012). Bu tür araştırmalar, büyük örneklem üzerinde çalışma imkanı sunmaktadır. Bu çalışma, ilkokul öğrencilerinin Empresyonizme yönelik görüşlerinin görsel okuryazarlık bağlamında ortaya çıkarılmasında görüşme formundan yararlanılması, öğrencilerin sanat eserlerini eleştirel olarak incelemesi, yorumlaması ve en önemlisi yaratıcı fikirlerini dile getirmesi açısından araştırmacıya yöntemini oluşturması için bir dayanak sağlamıştır.

\section{2. Çalışma Grubu}

Araştırmanın çalışma grubu, 2018-2019 eğitim-öğretim yılı güz döneminde Muş il merkezine bağlı, farklı sosyoekonomik özelliklere sahip, 18 ilkokulda öğrenim gören 526 ögrrenciden oluşturulmuştur. Çalışma grubu, amaçsal 
örnekleme yöntemlerinden maksimum çeşitlilik örnekleme yöntemi kullanılarak belirlenmiştir. Bu doğrultuda farklı özelliklere sahip öğrencilere ulaşılması amaçlanmıştır. Öğrencilerin gönüllülük esasına dayanılarak araştırmaya katılımları sağlanmıştır. Çalışma grubunda bulunan öğrencilerin demografik bilgileri Tablo 1'de verilmiştir.

Tablo 1. Çalışma Grubu ile İlgili Demografik Bilgilerin Dağılımları

\begin{tabular}{cccc}
\hline \multicolumn{2}{c}{ Demografik özellikler } & $\mathrm{n}$ & $\%$ \\
\hline \multirow{2}{*}{ Cinsiyet } & Kiz & 266 & 50,6 \\
& Erkek & 260 & 49,4 \\
\hline \multirow{2}{*}{ Sinıf Düzeyi } & 1. Sinıf & 128 & 24,3 \\
& 2. Sinıf & 127 & 24,1 \\
& 3. Sinıf & 137 & 26 \\
\hline Toplam & 4. Sinıf & 134 & 25,5 \\
\hline
\end{tabular}

Tablo 1'de görüldüğü gibi öğrencilerin \% 49,4'ü erkek, \% 50,6's1 kı olduğu, \% 24,3'̈̈ 1. sınıf, \% 24,1'i 2. sınıf, \% 26's1 3. sinıf ve \% 25,5'i 4. sinıfta öğrenim gördüğü belirlenmiştir. Buradan yola çıkarak çalışma grubunu oluşturan öğrencilerin demografik özelliklerinin dengeli bir şekilde dağılım gösterdiği söylenebilir.

\subsection{Veri Toplama Arac1}

Araştırmada belirlenen hedef doğrultusunda veri toplama araçlarını geliştirmek amacıyla birinci aşamada ilkokul öğrencilerinin ilgilerini arttıracak ve onlarda heyecan uyandıracak sanat eserleri belirlenmeye çalışılmıştır. $\mathrm{Bu}$ doğrultuda ilgili literatüre dayanarak öğrencilerin gündelik deneyimleri ile ilgili kolay tanımlanabilir konu ve renkleri barındıran sanat eserleri seçilmiştir. Aynı zamanda öğrencilerle görüşme esnasında, görsel unsurların tartışılmasına imkân verecek oldukça basit görseller tercih edilmiştir. Bu çerçevede Lopatovska ve diğerlerinin (2016) de önerdiği Empresyonizm sanat akımına mensup manzara resimlerinin tercih edilmesine karar verilmiştir. Yukarıda belirtilen çerçeve içerisinde Empresyonizm sanat akımının üç dönemine ait birer manzara resmi üç görsel sanatlar uzmanın görüşleri doğrultusunda seçilmiştir. Tercih edilen sanat eserleri Tablo 2'de sunulmuştur.
Tablo 2. Araştırmada Kullanılan Sanat Eserleri

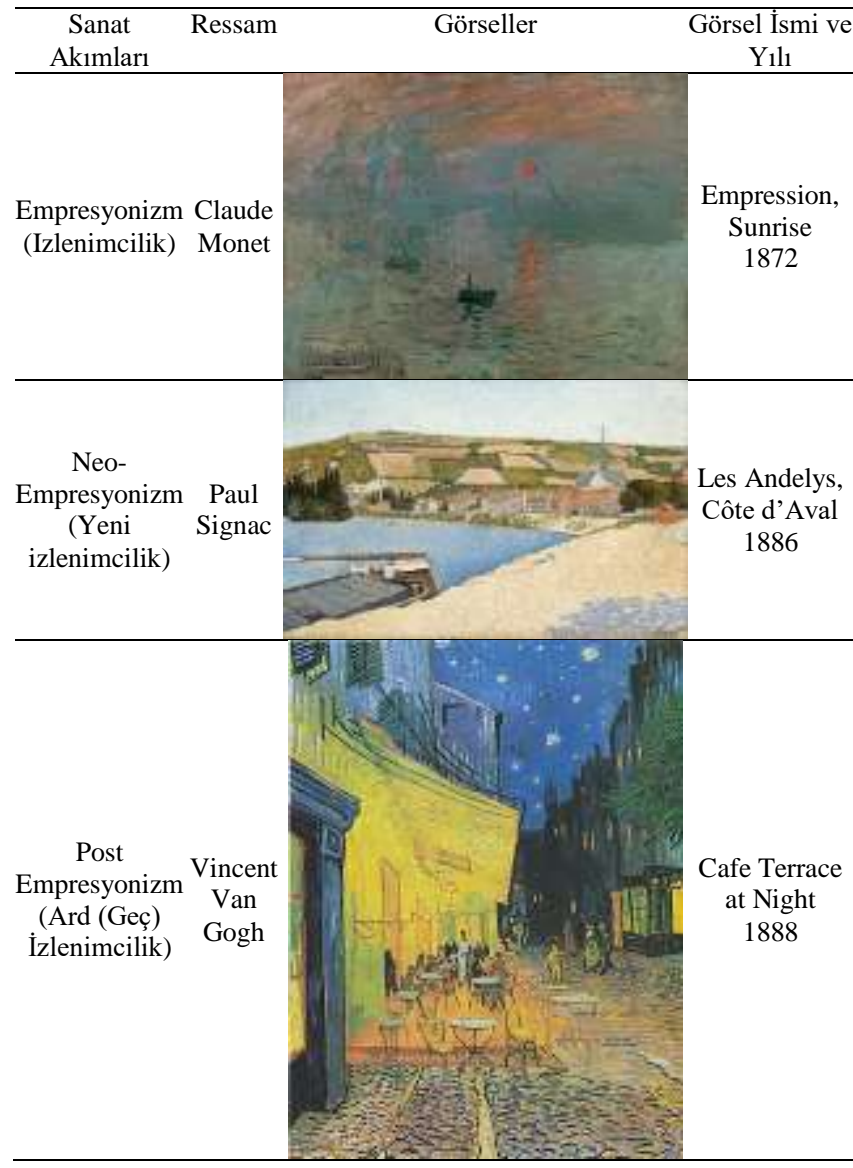

İkinci aşamada, Tablo 2'de belirlenen resimler çerçevesinde ilkokul öğrencilerinin Empresyonizm sanat akımına yönelik görüşlerini görsel okuryazarlık bağlamında incelemek amacıyla görüşme formu hazırlanmasına karar verilmiştir. Görsel okuryazarlık; bir görüntünün kompozisyon unsurlarını yorumlama, analiz etme ve yeniden tasarlama şeklinde tanımlanmaktadır. Bu doğrultuda görüşme formu hazırlanmıştır. Tasarlanan görüşme formu, alanında doktora yapmış iki uzman ve doçent unvanına sahip bir uzman olmak üzere toplam üç görsel sanatlar uzmanının görüşüne sunulmuştur. Görüşme formunda bulunan sorularla ilgili yanlış anlamlara sebep olabilecek yönlerin bulunup bulunmadığı, araştırmanın amacına uygun olup olmadığ gibi çeşitli değiş̧kenler açısından değerlendirilmek üzere uzman görüşü alınmış ve görüşme formuna son şekli verilmiştir.

Görüşmeler uygulanan kuralların katılığına göre; yapılandırılmış, yarı yapılandırılmış ve yapılandırılmamış olmak üzere üçe ayrilabilir (Çepni, 2007). Bu çalışmada araştırmanın amacına bağlı olarak yarı yapılandırılmış görüşme tekniği kullanılmıştır.

\subsection{Verilerin Toplanmas1}

$\mathrm{Bu}$ çalışmada temel veri toplama kaynağı olarak görüşme formu kullanılmıştır. Veri toplamak amacıyla Tablo 2'de verilen resimlerin renkli görsel kopyaları, sınıf ortamında görsel sanatlar öğretmenlerinin rehberliğinde çalışma grubundaki öğrencilere sunulmuştur. Görüşmeler 10 ile 15 dakika arasında sürmüştür. Veri toplama süreci ortalama 2 ayda tamamlanmıştır. $\mathrm{Bu}$ yöntem ile öğrencilerin 
Empresyonizm sanat akımına yönelik görüşlerinin, görsel okuryazarlık bağlamında belirlenmesi hedeflenmiştir.

Veri toplama araçları için Van Yüzüncü Yıl Üniversitesi Sosyal ve Beşeri Bilimleri Yayın Etik Kurul Başkanlığı'ndan görüşme formunun etik açıdan uygunluğuna yönelik onay alınmıştır. Etik kurulu onayı Ek1'de verilmiştir.

\subsection{Verilerin Analizi}

İlkokul öğrencilerinin Empresyonizme yönelik görüşlerinin görsel okuryazarlık bağlamında incelenmek amacıyla yapılmış olan görüşmeler ve bu görüşmeler sonucunda elde edilen nitel verilerin analizi için içerik analizi kullanılmıştır. İçerik analizi sadece metinler üzerine kullanılan bir yöntem değildir. Aynı zamanda görsellerin incelenmesinde de kullanılabilir (Yıldırım ve Şimşek, 2011).

Araştırmacı, ilk etapta öğrencilerin Tablo 2'de verilen sanat eserlerine yönelik ilgilerini belirlemek amaciyla sorulan "En sevdiğin resim hangisi?" sorusunu tanımlayıcı istatistiksel çerçevede analiz etmiştir. İkinci soru olan "Seçtiğiniz sanat eserini niçin veya neye göre seçtiniz?" sorusu içerik analizi yöntemi ile çözümlenmiştir. Bu doğrultuda 10 erkek ve $10 \mathrm{k} 1 \mathrm{z}$ öğrenci olmak üzere toplam 20 öğrenci ile ön uygulama çalışması yapılmıştır. Bu soruya yönelik ön uygulama çalışmasında elde edilen veriler, iki Görsel Sanatlar eğitimi uzmanı tarafından incelenmiştir. Bu doğrultuda kodlar (sanat eserinin konusu ve görselin dikkat çekiciliği) belirlenerek "Öğrencilerin sanat eserlerine yönelik ilgi duyma nedenleri" şeklinde isimlendiren temanın altına yerleştirilmiştir. Uzmanlar, kodlar ve temayı tartışarak uzlaşma yoluyla belirlemiştir. Uzlaşılmayan noktalarda ise alanında doçent unvanına sahip üçüncü uzmanın görüşüne başvurulmuş ve uzlaşma yoluna gidilmiştir. Örneğin, renklerin dikkat çekiciliği ve şekillerin dikkat çekiciliği şeklinde isimlendirilen iki koda yönelik uzmanların uzlaşamadığı görülmüştür. Bu doğrultuda bu kodları üçüncü uzman görüşü doğrultusunda görselin dikkat çekiciliği şeklinde isimlendirilmiştir. Çalışma grubundan elde edilen veriler belirlenen kodlar doğrultusunda SPSS 17.0 paket programına girilmiştir. Bu program aracılığ veriler tanımlayıcı istatistiksel çerçevede analiz edilmiştir. Daha sonra "Resimde ne görüyorsunuz, resimde nasıl bir değişiklik yapmak isterdiniz?" soruları, görsel okuryazarlık bağlamında analiz edilmiştir. Bu bağlamda, öğrencelerin belirlenen sanat eserlerinin kompozisyon unsurlarını yorumlama, analiz etme ve tekrar tasarlaması amaçlanmıştır. Öğrencilerin tanımlayabildikleri, eklemek ve çıkartmak istedikleri her bir unsur sayılmıştır. Bu unsurlar, "Görsel okur ve görsel yazarlık" temasına yerleştirilmiştir. Daha sonra tanımlayıcı istatistiksel çerçevede ortalamaları alınarak çözümlenmiştir. Ayrıca verilerin geçerliliğini arttırmak amacıyla katılımcıların görüşlerine başvurulmuştur. Bu doğrultuda erkek öğrenciler $\mathrm{E} 1, \mathrm{E} 2$; k1z öğrenciler ise $\mathrm{K} 1, \mathrm{~K} 2$ şeklinde formüle edilerek doğrudan alıntılara yer verilmiştir.

\section{Bulgular ve Yorumlar}

Araştırmanın birinci alt problemi kapsamında "Öğrencilerin ilgi duydukları sanat eserleri cinsiyetlerine ve sınıf düzeylerine göre değişmekte midir?” sorusuna cevap aranmıştır. Yapılan analizler sonucunda birinci alt probleme ilişkin bulgular Tablo 3 'te sunulmuştur.

Tablo 3. Öğrencilerin İlgi Duydukları Sanat Eserleri

\begin{tabular}{|c|c|c|c|c|c|}
\hline \multicolumn{2}{|c|}{ Değişkenlerf/\% } & $\begin{array}{l}\text { 1. Görsel } \\
\text { (Claude } \\
\text { Monet, } \\
\text { Izlenimcilik) }\end{array}$ & $\begin{array}{c}\text { 2. Görsel } \\
\text { (Paul } \\
\text { Signag, Yeni } \\
\text { izlenimcilik) }\end{array}$ & $\begin{array}{c}\text { 3. Görsel } \\
\text { (Vincent Van } \\
\text { Gogh, Ard } \\
\text { İzlenimcilik) }\end{array}$ & Toplam \\
\hline \multirow[t]{2}{*}{$\mathrm{K} 1 \mathrm{Z}$} & $\mathrm{f}$ & 88 & 79 & 99 & 266 \\
\hline & $\%$ & 33,1 & 29,7 & 37,2 & 100 \\
\hline \multirow[t]{2}{*}{ Erkek } & $\mathrm{f}$ & 69 & 104 & 87 & 260 \\
\hline & $\%$ & 26,5 & 40 & 33,5 & 100 \\
\hline \multirow[t]{2}{*}{ 1. sinif } & $\mathrm{f}$ & 41 & 38 & 49 & 128 \\
\hline & $\%$ & 32 & 29,7 & 38,3 & 100 \\
\hline \multirow[t]{2}{*}{ 2. $\sin 1 f$} & $\mathrm{f}$ & 40 & 43 & 44 & 127 \\
\hline & $\%$ & 31,5 & 33,9 & 34,6 & 100 \\
\hline \multirow[t]{2}{*}{ 3. sinif } & $\mathrm{f}$ & 40 & 51 & 46 & 137 \\
\hline & $\%$ & 29,2 & 37,2 & 33,6 & 100 \\
\hline \multirow[t]{2}{*}{ 4. sinif } & $\mathrm{f}$ & 36 & 51 & 47 & 134 \\
\hline & $\%$ & 26,9 & 38,1 & 35,1 & 100 \\
\hline \multirow[t]{2}{*}{ Toplam } & $\mathrm{f}$ & 157 & 183 & 186 & 526 \\
\hline & $\%$ & 29,8 & 34,8 & 35,4 & 100 \\
\hline
\end{tabular}

Tablo 3 incelendiğinde, öğrencilerin en çok tercih ettikleri sanat eserinin ard izlenimcilik dönemine ait 3. görsel $(\% 35,4)$ olduğu görülmektedir. Erkeklerin daha çok yeni izlenimcilik dönemine ait 2. görseli (\%40), kızların ise ard izlenimcilik dönemine ait 3 . görseli $(\% 33,5)$ tercih ettikleri belirlenmiştir. 1. sınıf $(\% 38,3)$ ile 2. Sınıf $(\% 34,6)$ düzeyinde öğrenim gören öğrencilerin daha çok ard izlenimcilik dönemine ait 3 . görseli tercih ettikleri, 3. sınıf $(\% 37,2)$ ile 4. sınıf $(\% 38,1)$ düzeyinde öğrenim gören öğrencilerin daha çok yeni izlenimcilik dönemine ait 2 . görseli tercih ettikleri tespit edilmiştir. Bu doğrultuda alınan öğrenci görüşlerinden birkaçı aşağıda verilmiştir:

“Üçüncü resim hoşuma gitti...” E170.

“Birinci resim gerçekten harika gözüküyor...” K2.

"İkinci resmi beğendim. Bu resme baktı̆̆ımda oturup konuşabileceğim, balık tutabileceğim yerler var.” E3.

Öğrenci görüşleri dikkate alındığında, ilkokul öğrencilerinin Empresyonizm sanat akımının son dönemlerine ait eserlere daha çok ilgi duydukları söylenebilir. Öğrencilerin bazı görselleri yaşadıkları bölgelere benzeterek açıkladıkları görülmüştür. Ayrıca öğrencilerin keskin kontörlerle belirlenmiş somut görsellere daha çok ilgi duydukları belirlenmiştir.

Araştırmanın ikinci alt problemi kapsamında "Öğrencilerin sanat eserlerine yönelik ilgi duyma nedenleri cinsiyetlerine ve sınıf düzeylerine göre değişmekte midir?" sorusuna cevap aranmıştır. Yapılan analizler sonucunda ikinci alt probleme ilişkin veri analizleri Tablo 4'te verilmiştir. 
Tablo 4. Öğrencilerin Sanat Eserlerine Yönelik İlgi Duyma Nedenleri

\begin{tabular}{|c|c|c|c|c|}
\hline Değişkenler & $\mathrm{f} / \%$ & $\begin{array}{c}\text { Sanat Eserin } \\
\text { Konusu }\end{array}$ & $\begin{array}{c}\text { Görselin } \\
\text { Dikkat } \\
\text { Çekiciliği }\end{array}$ & Toplam \\
\hline \multirow[t]{2}{*}{$\mathrm{K} 1 \mathrm{z}$} & $\mathrm{f}$ & 159 & 107 & 266 \\
\hline & $\%$ & 59,8 & 40,2 & 100 \\
\hline \multirow[t]{2}{*}{ Erkek } & $\mathrm{f}$ & 166 & 94 & 260 \\
\hline & $\%$ & 63,8 & 36,2 & 100 \\
\hline \multirow[t]{2}{*}{ 1. sinif } & $\mathrm{f}$ & 72 & 56 & 128 \\
\hline & $\%$ & 56,3 & 43,8 & 100 \\
\hline \multirow[t]{2}{*}{ 2. sinif } & $\mathrm{f}$ & 73 & 54 & 127 \\
\hline & $\%$ & 57,5 & 42,5 & 100 \\
\hline \multirow[t]{2}{*}{ 3. sinif } & $\mathrm{f}$ & 95 & 42 & 137 \\
\hline & $\%$ & 69,3 & 30,7 & 100 \\
\hline \multirow[t]{2}{*}{ 4. sinif } & $\mathrm{f}$ & 85 & 49 & 134 \\
\hline & $\%$ & 63,4 & 36,6 & 100 \\
\hline \multirow[t]{2}{*}{ Toplam } & $\mathrm{f}$ & 325 & 201 & 526 \\
\hline & $\%$ & 61,8 & 38,2 & 100 \\
\hline
\end{tabular}

Tablo 4'teki verilere göre öğrencilerin ilgi duydukları görselleri, daha çok eserin konusunu $(\% 61,8)$ temel alarak seçtikleri görülmüştür. Dolayısıyla eserin konusunun öğrencilerin sanat eserlerine yönelik ilgilerini belirlemede etkili olduğu söylenebilir. Bu doğrultuda alınan öğrenci görüşlerinden birkaçı aşağıda verilmiştir.

"Renkleri beğendim. Özellikle denizin parılttsını iyi işlediğinden dolayı seçtim" K200.

"Güneşin doğuşunu güzel yansittığından dolayı birinci resmi beğendim” E5.

"Evleri, suyu, denizi beğendimden dolayı seçtim" K112.

"Üçüncü resim konuyu diğerlerinden farklı ve çok canlı işlemiştir" E180.

“Eskiyi anımsattı̆̆ için seçtim” K6.

Öğrenci görüşleri dikkate alındığında, öğrencilerin görsellere yönelik ilgilerini çeken unsurları açıkladıkları görülmektedir. $\mathrm{Bu}$ açıklamalardan hareketle sanat eserin konusu ve görselin dikkat çekiciliği öğrencilerin görsellere yönelik ilgisini çeken ana unsurlardan birisi olduğu söylenebilir.

Araştırmanın üçüncü alt problemi kapsamında "Öğrencilerin görsel okur ve görsel yazarlık unsurlarına yönelik açıklamaları sanat eserlerine, cinsiyetlerine ve sınıf düzeylerine göre nasıl bir dağılım göstermektedir?" sorusuna cevap aranmıştır. Elde edilen analizler sonucunda üçüncü alt probleme ilişkin bulgular Tablo $5^{\prime}$ te sunulmuştur.
Tablo 5. Öğrencilerin Görsel Okur ve Görsel Yazarlık Unsurlarına Yönelik Açılamalarının Ortalamaları

\begin{tabular}{|c|c|c|c|c|}
\hline Tema & Değişkenler & $\begin{array}{c}\text { 1.Görsel } \\
\text { (Claude } \\
\text { Monet, } \\
\text { İzlenimcilik) } \\
\end{array}$ & $\begin{array}{l}\text { 2. Görsel } \\
\text { (Paul } \\
\text { Signag, Yeni } \\
\text { izlenimcilik) }\end{array}$ & $\begin{array}{c}\text { 3. Görsel } \\
\text { (Vincent Van } \\
\text { Gogh, Ard } \\
\text { izlenimcilik) }\end{array}$ \\
\hline \multirow{7}{*}{$\begin{array}{l}\text { Görsel } \\
\text { Okur }\end{array}$} & $\mathrm{K} 1 \mathrm{z}$ & 4,24 & 5,04 & 5,14 \\
\hline & Erkek & 4,18 & 5,14 & 5,13 \\
\hline & 1. sinif & 3,82 & 4,59 & 4,98 \\
\hline & 2. $\sin 1 f$ & 4,25 & 5,24 & 5,38 \\
\hline & 3. $\sin 1 f$ & 4,23 & 5,18 & 4,97 \\
\hline & 4. $\sin 1 f$ & 4,53 & 5,34 & 5,22 \\
\hline & Toplam & 4,21 & 5,09 & 5,14 \\
\hline \multirow{7}{*}{$\begin{array}{c}\text { Görsel } \\
\text { Yazarlık }\end{array}$} & K1z & 3,50 & 3,65 & 3,64 \\
\hline & Erkek & 3,50 & 3,49 & 3,53 \\
\hline & 1. sinif & 3,09 & 2,98 & 3,14 \\
\hline & 2. sinif & 3,72 & 3,91 & 3,75 \\
\hline & 3. sinif & 3,11 & 3,08 & 3,07 \\
\hline & 4. $\sin 1 f$ & 4,07 & 4,32 & 4,37 \\
\hline & Toplam & 3,50 & 3,57 & 3,58 \\
\hline
\end{tabular}

Tablo 5 incelendiğinde öğrencilerin 1. görselin görsel unsurlarını yorumlama, analiz etme (görsel okur, 4,21) ve tekrar tasarlamaya (görsel yazarlık, 3,50) yönelik açıklamalarının, diğer görsellere göre daha az olduğu görülmektedir. Ancak öğrencilerin 3. görselin görsel okur $(5,14)$ ve görsel yazarlık unsurlarına $(3,58)$ yönelik açılamalarının diğer görsellere göre daha fazla olduğu görülmüsstür. $\mathrm{Bu}$ doğrultuda öğrencilerin empresyonizm sanat akımının son dönemine ait eserlere yönelik görsel okuryazarlık becerilerinin daha yüksek olduğu söylenebilir. Tablo 5 incelenmeye devam edildiğinde, öğrencilerin görsel okur unsurlarına yönelik açıklamalarının (1. görsel, 4,21; 2 . görsel, 5,09; 3. görsel, 5,14) görsel yazarlık unsurlarına yönelik açıklamalarına (1. görsel, 3,50; 2. görsel, 3,57; 3 . görsel, 3,58) göre daha fazla olduğu tespit edilmiştir. Ayrıca 4. sınıf düzeyinde öğrenim gören öğrencilerin görsel okur (1. görsel, 4,53; 2. görsel, 5,34; 3. görsel, 5,22) ve görsel yazarlık unsurlarına (1. görsel, 4,07; 2. görsel, 4,32; 3. görsel, 4,37) yönelik açıklamalarının 1., 2. ve 3. sınıf düzeyinde öğrenim gören öğrencilere göre daha fazla olduğu görülmüştür

\section{Tartışma, Sonuç ve Öneriler}

Son yıllarda görsel okuryazarlık tanımlamaları geleneksel metin tabanlı yorumlanmanın ötesine geçmiştir (Lopatovska ve diğ., 2016). Özellikle dijital teknolojilerin çoğalmasıyla birlikte düşünce dünyamızda yeni bir paradigmanın ortaya çıktığı söylenebilir. Dolayısıyla görsel kültürün etkisinin arttığı bir dünyada öğrencilerin görsel okuryazarlık becerilerinin geliştirilmesi önem arz etmektedir (Sadik, 2009; Yerlikaya, 2016). Bu doğrultuda araştırmada belirlenen sanat eserleri çerçevesinde öğrencilerin sanat eserlerini, eleştirel olarak incelemesi, yorumlaması ve en önemlisi yaratıcı fikirlerini dile getirmesi amaçlanmaktadır. Bu bağlamda araştırmanın sonuçları incelendiğinde, genel olarak öğrencilerin belirlenen görsellere yönelik olumlu tepki gösterdikleri ve onlara yöneltilen soruları yanıtladıkları görülmüştür. Örs (2015) yapmış olduğu araştırmada, öğrencilerin etkinlikteki görseller yoluyla cümle kurmakta sıkıntı çekmediklerini dile getirmektedir. Ayrıca Stewig (1994), yaptığı çalışmada görsel okuryazarlık etkinliklerinin öğrencilerin sanat 
hakkında yaratıcı fikirlerini dile getirmelerinde etkili olduğunu ifade etmektedir.

Araştırmanın birinci alt problemi kapsamında elde edilen sonuçlar incelendiğinde, öğrenciler tarafından en çok tercih edilen görselin Van Gogh'un "Teras Kafede Gece” adlı tablosu olduğu görülmüştür. Benzer bir sonuç Lopatovska ve dĭg. (2016) tarafindan yapılan araştırmada da görülmektedir. Öğrencilerin Monet'in yapmış olduğu "Gün Doğumu" adlı görsele yönelik ilgilerinin daha az olduğu belirlenmiştir. Öğrencilerin soyut bir sanat eserini incelediklerinde, fikirleri veya duygularıyla değil bildikleri fenomenleriyle hareket ettikleri görülmüştür (Yenawine, 1999). "Gün Doğumu” görselinin öğrenciler için biraz soyut kaldığı, dolayısıyla öğrencilerin tercihlerini etkilediği söylenebilir. $\mathrm{Bu}$ doğrultuda belirlenen görseller içerisinde öğrencilerin Empresyonizm sanat akımının son dönemine ait görselleri daha çok sevdiği söylenebilir. Ancak Savva (2003) yapmış olduğu araştırmada çocukların daha çok soyut resimlere yönelik ilgi duydukları görülmektedir. $\mathrm{Bu}$ sonuç araştırmada elde edilen sonuçla çelişmektedir.

Araştırmanın ikinci alt problemi kapsamında elde edilen sonuçlar incelendiğinde, öğrencilerin ilgi duydukları sanat eserlerini daha çok eserin konusunu dikkate alarak seçtikleri tespit edilmiştir. $\mathrm{Bu}$ bulgu, öğrencilerin sanat eserlerine yönelik ilgilerini belirlemede, görselin dikkat çekiciliğinden çok eserin konusunun belirleyici olduğu ve onları etkilediği söylenebilir. Benzer bir sonuç Gardner'ın (1970) yaptığı araştırmada da görülmektedir. Anacak Lopatovska ve diğerlerinin (2016) ortaya koydukları çalışmada, canlı renklerin varlığının çocukların görsellere yönelik ilgisini çeken ana unsurlardan birisi olduğunu ifade etmektedir. Ancak bu tespit araştırmamızın sonuçları ile çelişmektedir.

Araştırmanın üçüncü alt problemi kapsamında elde edilen sonuçlar doğrultusunda, öğrencilerin belirlenen sanat eserlerinin görsel unsurlarını yorumlama, analiz etme ve tekrar tasarlamaya yönelik yaratıcı görüşlerinin olduğu görülmüştür. Öğrencilerin Monet'in yapmış olduğu izlenimcilik dönemine ait "Gün Doğumu” görselinin görsel okur ve yazarlık unsurlarına yönelik açıklamalarının diğer görsellere göre daha az olduğu belirlenmiştir. Bu durumun "Gün Doğumu" görselinin diğer görsellere göre nispeten daha soyut olmasından kaynaklandığı söylenebilir. Öte yandan ögrrencilerin Van Gogh'un "Teras Kafede Gece" adlı görseli, görsel okur ve görsel yazarlık unsurlarına yönelik açıklamalarının diğer görsellere göre daha fazla olduğunu tespit edilmiştir. Ayrıca birinci alt problemden elde edilen sonuçlar, öğrencilerin "Gün Doğumu” görseline yönelik ilgilerinin diğer görsellere göre daha az olduğunu, "Teras Kafede Gece" adlı görseline yönelik ilgilerinin diğer görsellere göre daha fazla olduğunu ortaya koymaktadır. $\mathrm{Bu}$ doğrultuda öğrencilerin sevdiği sanat eserlerine yönelik daha fazla açıklamada bulundukları söylenebilir. Dolayısıyla öğrencilerin ilgi duydukları sanat eserlerinin görsel okuryazarlık becerilerini etkilediği dile getirilebilir.

Araştırmanın üçüncü alt problemi kapsamında elde edilen önemli sonuçlardan biri de öğrencilerin görsel yazarlık unsurlarına yönelik açıklamalarının, görsel okur unsurlarına yönelik açıklamalarına göre daha az olduğudur. $\mathrm{Bu}$ doğrultuda öğrencilerin görselleri anlama ve yorumlama konusunda başarılı oldukları ancak görseli tekrar tasarlama (görsel yazarlık) konusunda görsel okura göre zayıf kaldıkları söylenebilir. Ayrıca 4. sınıf düzeyinde öğrenim gören öğrencilerin görsel okur ve görsel yazarlık unsurlarına yönelik açıklamalarının diğer sınıf düzeyinde öğrenim gören öğrencilere göre daha fazla olduğu görülmüştür. $\mathrm{Bu}$ doğrultuda öğrencilerin süreç içerisinde aldıkları eğitimlerin kazandıkları deneyimlerin veya zihinsel gelişimlerinin görsel okuryazarlık becerilerini etkilediği dile getirilebilir. Yapılan araştırmalarda çocukların sanat eserlerine yönelik tercihlerinin, algılarının ve yanıtlarındaki farklılıkların bilişsel farklılıklara bağlı olduğu görülmektedir (Gardner, Winner ve Kircher, 1975; Parsons, Johnston ve Durham 1978; Savva 2003).

Çocuklara, bir sanat eserini inceledikten sonra düşüncelerini ifade etmeleri için fursatlar sunulduğunda, çocuklar yaratıcılıklarını geliştirebilmektedirler (Pavlou, 2013). Bu bağlamda araştırmada elde edilen sonuçlara dayanarak ilkokul öğrencilerinin farklı sanat eserlerine yönelik görsel okuryazarlık çerçevesinde düşüncelerini ifade edebileceği ortamların oluşturulması önerilmektedir. $\mathrm{Bu}$ ortamlarda araştırmanın birinci alt problemi doğrultusunda elde edilen sonuçlara göre, öğrencilerin algılayabileceği somut görseller seçilmelidir. Ayrıca araştırmanın ikinci ve üçüncü alt probleminden elde edilen sonuçlardan hareketle öğrencilerin ilgi duyabilecekleri görseller tercih edilmelidir. $\mathrm{Bu}$ tür etkinliklere öğrenmeöğretme ortamında daha fazla yer verilmelidir. Buradan hareketle Görsel Sanatlar eğitimi dersine giren öğretmenlere, öğrencilerin görsel okuryazarlık becerilerini geliştirmeye yönelik hizmet içi ve hizmet öncesi eğitim verilmelidir. Ayrıca ilgili araştırmacılara, farklı sanat akımlardan farklı görselleri kullanarak öğrencilerin bu görsellere yönelik görüşlerinin görsel okuryazarlık bağlamında incelenmesine yönelik araştırmalar yapmaları önerilebilir.

\section{Kaynakça}

Ayaydın, A. (2015). Empresyonizm (izlenimcilik) akımının güncel bakış açısıyla bazı yönlerden incelenmesi. Sanat Ë̌itimi Dergisi, 2(3), 83-97.

Brown, I. (2004). Global trends in art education: New technologies and the paradigm shift to visual literacy. The International Journal of Arts Education, 2(3), 5061.

Creswell, J. W. (2012). Educational research: Planning, conducting, and evaluating quantitative and qualitative research. (4th ed.). Boston: Pearson Education.

Çakıroğlu, E. ve İnce, B. (2015). Visual arts teacher candidates' views on conceptual art (Case of Pamukkale University). Procedia-Social and Behavioral Sciences, 191, 2817-2823.

Çepni, S. (2007). Araştırma ve proje çalışmalarına giriş. (3. Bask1). Trabzon: Celepler Matbaacılık.

Flynt, E. S. ve Brozo, W. (2010). Visual literacy and the content classroom: A question of now, not when. The Reading Teacher, 63(6), 526-528.

Gardner, H. (1970). Children's sensitivity to painting styles. Child Development, 41, 813-821. 
Gardner, H., Winner, E. ve Kircher, M. (1975). Children's conceptions of the arts. Journal of Aesthetic Education, 9(3), 60-77.

Karasar, N. (1991). Bilimsel araştırma yöntemi. (4. Bask1). Ankara: Sanem.

Lopatovska, I., Hatoum, S., Waterstraut, S., Novak, L. ve Sheer, S. (2016). Not just a pretty picture: Visual literacy education through art for young children. Journal of Documentation, 72(6), 1197-1227.

Loerts, T. ve Belcher, C. (2019). Developing visual literacy competencies while learning course content through visual journaling: Teacher candidate perspectives. Journal of Visual Literacy, 2(38), 46-65.

MEB (2018). Ilkokul ve ortaokul görsel sanatlar dersi ögretim programı (1-8. sinıflar). Ankara: MEB Yayınları.

Metros, S. E. (2008). The educator's role in preparing visually literate learners. Theory into Practice, 47(2), 102-109.

Meyer, R. (2010). Knowledge visualization. Trends in Information Visualization, 23-30. Erişim adresi: http://www.mmi.ifi.lmu.de/pubdb/publications/pub/baur 2010infovisHS/baur2010infovisHS.pdf\#page $=31$ 08/03/2020 tarihinde erişilmiștir.

O'Neil, K. E. (2011). Reading pictures: Developing visual literacy for greater comprehension. The Reading Teacher, 65(3), 214-223.

Örs, E. (2015). Ikkinci sınıf öğrencilerinin görsel okuryazarlı̆̆ üzerine bir araştırma (Yayınlanmamış yüksek lisans tezi). İstanbul Aydın Üniversitesi Sosyal Bilimler Enstitüsü, İstanbul.

Pantaleo, S. (2016). Primary students' understanding and appreciation of the artwork in picturebooks. Journal of Early Childhood Literacy, 16(2), 228-255.

Parsons, M., Johnston, M. ve Durham, R. (1978). Developmental stages in children's aesthetic responses. Journal of Aesthetic Education, 12(1), 83-104.

Pavlou, V. (2013). Investigating interrelations in visual arts education: Aesthetic enquiry, possibility thinking and creativity. International Journal of Education Through Art, 9(1), 71-88.

Prensky, M. (2001). Digital natives, digital immigrants. On the Horizon, 9(5), 1-6.

Roblyer, M. D. ve Bennett, E. K. (2001). The fifth literacy: Research to support a mandate for technology-based visual literacy in preservice teacher education. Journal of Computing in Teacher Education, 17(2), 8-15.

Sadik, A. (2009). Improving pre-service teachers' visual literacy through flickr. Procedia-Social and Behavioral Sciences, 1(1), 91-100.

Savva, A. (2003). Young pupils' responses to adult works of art. Contemporary Issues in Early Childhood, 4(3), 300-313.

Stewig, J. W. (1994). First graders talk about paintings. The Journal of Educational Research, 87(5), 309-316.

Şahin, Ç. ve Kıran, I. (2009). Öğretmen adaylarının algılarına göre görsel okuryazarlık düzeylerinin değerlendirilmesi. Dumlupınar Üniversitesi Sosyal Bilimler Dergisi, 23, 77-90.

Taşpınar, Ş. E. (2016). Sanat eğitiminin görsel okuryazarlık becerilerine etkisi. The Turkish Online Journal of Design, Art and Design (TOJDAC), 1(6), 335-342.

Tansuğ, S. (2006). Resim sanatının tarihi. İstanbul: Remzi Kitabevi.

Wileman, E. (1993). Visual communicating. Englewood Cliffs, N.J.: Educational Technology Publications.

Yenawine, P. (1999). Theory into practice: The visual thinking strategies. Paper presented at the conference, "Aesthetic and Art Education: A Transdisciplinary Approach," sponsored by the Caluste Gulbenkian Foundation, Lisbon, Portugal.

Yerlikaya, M. (2016). Arts and crafts teacher candidates' visual literacy skills. Participatory Educational Research, (4), 83-90.

Yıldırım, A. ve Şimşek, H. (2011). Sosyal bilimlerde nitel araştırma yöntemleri (8. Baskı). Ankara: Seçkin. 
EK 1: Etik Kurul Onay1

Evrak Tarih ve Sayısı: 03/03/2020-18242

\begin{tabular}{|c|c|c|}
\hline & $\begin{array}{l}\text { T.C. } \\
\text { VAN YÜZÜNCÜ YIL ÜNIVERSITESİ } \\
\text { SOSYAL VE BEŞERİ BİİMLERI YAYIN } \\
\text { ETIK KURUL BAŞKANLIĞI } \\
\text { ETIKK KURUL KARARLARI }\end{array}$ & \\
\hline $\begin{array}{l}\text { TOPLANTI TARI } \\
\text { OTURUM SAYISI } \\
\text { TOPLANTIDA AI }\end{array}$ & $\begin{array}{l}28.01 .2020 \\
020 / 01 \\
\text { IAN KARAR SAYISI: } 17\end{array}$ & Sayfa: $14 / 17$ \\
\hline
\end{tabular}

Van Yüzüncü Yll Üniversitesi Sosyal ve Beşeri Bilimleri Yayın Etik Kurulu'nun 28/01/2020 tarihinde saat 11.00' da Van Yüzüncü Yıl Üniversitesi Strateji Daire Bașkanlığı toplantı salonunda Prof. Dr. Orhan DENIZ başkanlığında yapmış olduğu toplantıda aşağıdaki karar/kararlan almıştır:

KARAR NO 2020/01-14. Yürütücülüğünü Eğitim Fakültesi, Resim-İ̧ Eğitimi Anabilim Dalı öğretim üyesi Dr. Ōğr. Üyesi Yahya HiÇYILMAZ'm yapmayı tasarladığı, "illkokul Öğrencilerinin Empresyonizme Yönelik Görüşlerinin Görsel Okuryazarlık Bağlaminda İncelenmesi” adlı çalı̧̧masmda kişilere uygulanacak olan anket ve ölçekler incelenmiş olup, söz konusu araçlarm ilgili kişilere uygulanmasında Sosyal ve Beşeri Etik Kurallan ve İlkeleri çerçevesinde herhangi bir sakmca olmadığına karar verilmiştir.

\begin{tabular}{|c|c|c|}
\hline & $\begin{array}{c}\text { BASKAN } \\
\text { Prof. Dr. Orhan DENIZ } \\
\text { Edebiyat Fakültesi }\end{array}$ & \\
\hline UYE & UYE & $\overline{\text { UYE }}$ \\
\hline $\begin{array}{l}\text { Prof. Dr. Mehmet Sirin CIXAR } \\
\text { Ilahiyat Fasültesi }\end{array}$ & $\begin{array}{l}\text { Prof. Dr. Hayati AYDIN } \\
\text { Ilahiyat Fakuiltesi } \\
\text { (Katalmadi) }\end{array}$ & $\begin{array}{l}\text { Prof. Dr. Reha SAYDAN } \\
\text { İktisadi ve İd Bil. Fakültesi }\end{array}$ \\
\hline UYE & UYE & UYE \\
\hline $\begin{array}{l}\text { Prof. Dr. Metin AYIȘIĞI } \\
\text { Edebiyat Fakuiltesi }\end{array}$ & $\begin{array}{l}\text { Prof. Dr. Hasan ÇiÇEK } \\
\text { Eğgitim Faluiltesi }\end{array}$ & $\begin{array}{l}\text { Prof. Dr. Zihni MEREY } \\
\text { Eğgitim Falkültesi } \\
\text { (Katulmadi) }\end{array}$ \\
\hline
\end{tabular}

